(TRJ) Tourism Research Journal

E-ISSN: 2598-9839

2020, Vol. 4 No. 1

\title{
The Role of Advertising in Social Media on Holiday Destinations Choice Among the Millennial Travelers
}

\author{
Anisatul Auliya \\ University Of Indonesia \\ anisatul.auliya@ui.ac.id
}

\begin{abstract}
Social Media has a big influence in tourism industry, social media also played as a role in tourism marketing, It has a major effectiveness as a marketing tool and performs with multiple functions. The purpose of this study to discussing the importance of social media when choosing a holiday destinations for the millennial traveler. This paper was conducted in January - April 2020 using descriptive quantitative research methods. The data collection technique of this research is survey analysis. Primary data is collected by questionnaire. There were 72 questionnaires have been distributed according the number of active students at second semester from tourism study in Vocational Education Program, University of Indonesia academic year 2019/2020. After the questionnaires were completed, SPSS 25 version is used to analyze the data. According to the result of this study, social media has a big influences when choosing the holiday destination. Instagram and YouTube are the most important media social platform to get the information and building the trust about the tourism destination.
\end{abstract}

Keywords: social media, holiday destination, tourism, millennial traveler 


\section{A. Introduction}

Tourism is firmly established because the most preferred in several countries and quickest growing economic sector in term of source of state income dan job creations for the local people. According to the World Travel \& Tourism Council, the Tour and tourism business is presently among the most important and fastestgrowing industries worldwide, and is predicted to produce over 328 million jobs, or $10 \%$ of the world's workplace by the year 2022. World Travel \& Tourism Council (WTTC) giving the suggestion to all those involved in managing tourism activities must be concern to all Factors influencing the visitors around the world, such as a destination's attractiveness and the knowledges of visitors, will continue to affect traveler behavior in the coming year.

The straight contribution of Travel \& Tourism to GDP (Gross Domestic Product) in 2018 was USD $2,750.7 \mathrm{bn}(3.2 \%$ of GDP). This is forecast to rise by $3.9 \%$ to USD 2.849.2bn in 2019. WTTC inform that various kinds of visitors motivations, the factor that the most encourages tourists to travel is for Leisure. Leisure travel is the primary reason visiting all regions of the world except the Middle East, where visiting friends and relatives (VFR) predominates, whether for health whether religious purposes (UNWTO, 2019).

In most industries, especially in tourism sector technology have a great impact in all aspect of operations. Some of costumers across the tourism dan hospitality industry, use technology to finding actual condition, honest and update reviews and recommendations an essential element when arranging their holiday planning. consumers will trust the recommendations about the tourist destinations not only from advertising but also from social media platform to research their travel planning.

Trough social media accounts they can finding the information, assessment of alternatives, selecting choices and purchasing. Consumers can reach all the information about the tourism services for the holiday planning quickly.

Looking at the current conditions, in 2020 based on data obtained from we are social and hootsuite 2020 it was revealed that internet users around the world have now reached 4.5 billion people. from these data shows that internet users have reached nearly $60 \%$ of the world's population. Whereas if seen from the behavior of internet users that internet users in 2019 every day spend up to 6 hours 43 minutes.

In terms of social media users, of the 4.5 billion internet users worldwide, it turns out that 3.8 billion have used social media, according to the data stated that social media has actually become a new sphere of life and provides services that are quite dominant for the internet users. For more details, we can see the picture below about the number of social media users in the world. 


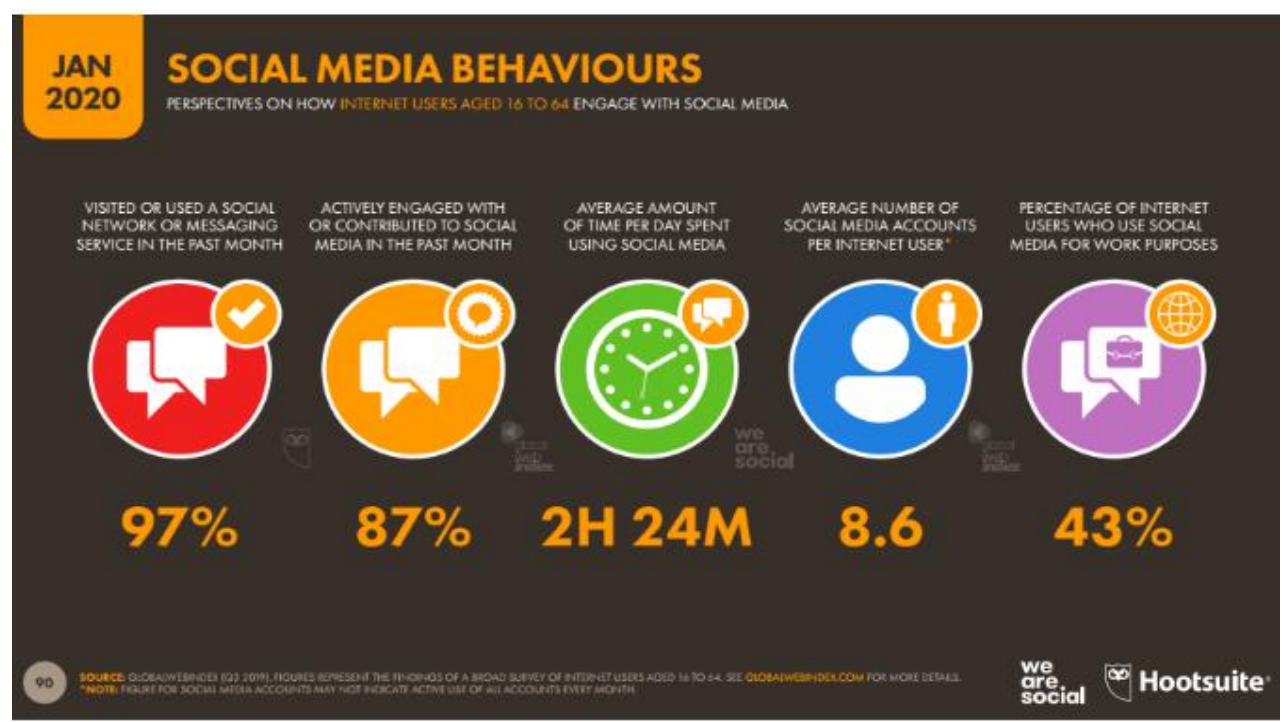

Figure 1: Social Media Behaviors in the world

Source: (We are Social dan Hootsuite, 2020)

According to Digital 2020 reports from we are social partnership with Hootsuite, it was informed that digital technology, mobile phone, and social media platform have become an indispensable part of everyday life for people all the world. Especially In Indonesia, Since January 2020, there were 175.4 million internet users. Between 2019 and 2020, the number of Internet users in Indonesia increased more by 25 million ( +17 per cent). In addition, according to social media users in Indonesia, the number of social media users in Indonesia grew by 12 million (+ 8.1 percent) between April 2019 and January 2020.

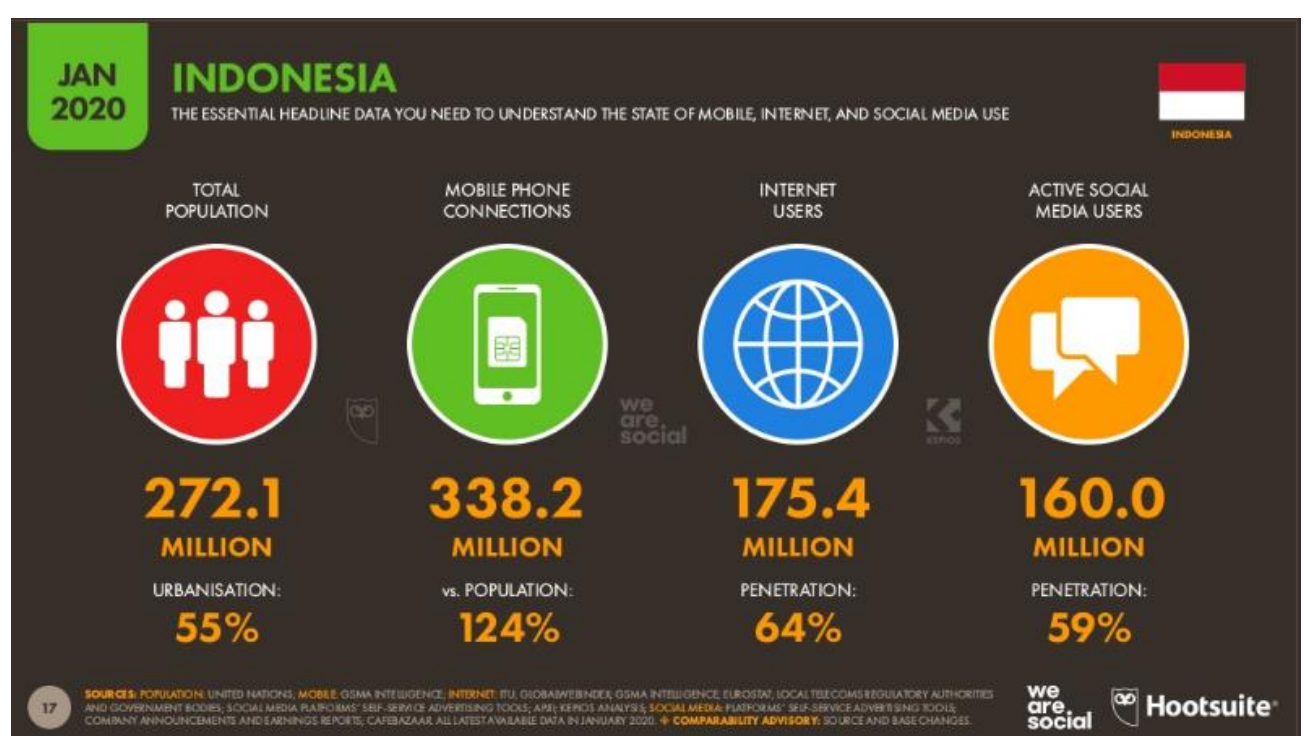

Figure 2: Mobile, Internet and Social Media Users In Indonesia Source: (We are Social dan Hootsuite, 2020) 
The improvement of technology in this world is very closely related to the development of the tourism and hospitality industry business sector, the development and progress of tourism today is strongly influenced by digital as a promotion technique. the results of research that has been done in several countries regarding the importance of social media in marketing or promoting various products within the scope of the hospitality and tourism industry and also social media greatly influence prospective tourists to determine their choice as a place to tour and fill holidays. As an example of the results of research conducted by (Kavoura \& Stavrianeas, 2015), results showed Differences between age groups as to the importance provided to social media as sources of tourism destination information have been established. The respondents find that online platforms when using the internet to gather knowledge about a Mediterranean destination for tourism., consider different online channels. Facebook is one of the most important sources of knowledge relating to tourism destinations for them. Official destination websites / blogs are the first source, and photo sharing sites are the second most preferred source; sharing photos aesthetics has been found to lead to a sense of belonging to an online travel community.

The uniqueness of this research is to examine the importance of social media in influencing millennials in their efforts to determine their tourist destinations choice for spending their holidays. Millennial generation is a generation of 15-34 years old. Since 2019, millennial travelers have become the main tourists market in Indonesia.

The purpose of this study is to find out the importance of social media to influencing the millennials tourist in determining the tourist destinations for spending their holidays. But only 5 (five) the social media platforms which will be examined, such as: facebook, youtube, instagram, twitter and blogging.

\section{B. Literature Review}

\section{Social Media}

What is the social media definition? Social, refers to the instinctual needs that people need to communicate with other people. We need to be in groups of like-minded people with whom we can feel at home and express our opinions, ideas and experiences comfortably (Safko, 2013), and the second term refers to the media We are creating such relations with other people. Whether it's drums, bells, the written word, telegraph, internet, radio, television, e-mail, websites, photos, audio, video, cell phones, or text messages, media is the technology we use to make those connections.

(Eley \& Tiley, 2009) Social media is a broad term for describing all the various forms of material that make up social networks: blog posts or blogs, images, audio, videos, links, social networking website profiles, status updates, and more. Social networking enables people with no coding or web development experience to easily upload and post unique content, and instantly share it with the world. 
Social media has emerged with growing impact as a strong, low-cost marketing tool with global reach. Visitors nowadays need information and are the recipients of communications marketing messages across a number of media platforms. It is, however, well known that online contact and social media have changed the contact landscape rapidly (Kavoura \& Stavrianeas, 2015).

With the latest technology, particularly young people under the age of 35 have begun to use internet and technical tools, smartphones and mobile apps and social media sites more frequently, and along with this, the rapid shift in technology and internet has begun to affect the tourism sector at a significant level (Sahin \& Sengün, 2015). Survey results show that the tourism preferences of the younger generation are influenced by social media and social media comments which have positive and negative effects on the tourism sector. In summary, when making tourism preferences social media users who share their experiences were mainly affected by comments.

Applications of social media come in several types. Let's find some of them:

a) Facebook

This social media, currently the largest and most popular social network on the Internet, connects people's real-world, we can do social interactions digitally in a wise online environment (Safko, 2013).

b) Youtube

on February 15, 2005 Early employees of PayPal Chad Hurley,Steve Chen, and Jawed Karim was activated the domain name YouTube.com. This platform that allows users to upload photos and videos to share with another people. And also, Youtube is also a wonderful place for Watching dan uploading the videos.

c) Instagram

Instagram, is one of popular social networking application service which is developed for smart phones and other mobile devices . this platform that allows users to share live videos, photographs and short videos (for written clarity we will use the term photograph or image to refer to both). All Users can also add a short description to their photographs and videos post them online apps. The uniqueness form this social media, These descriptions often take the form of "\#" hashtags, which allow users to insert their photo into a wider 'hashtag conversation'.

d) Twitter

One of Microblogging and social networking services that allow users to send and receive brief (140 characters or less) text-based, micro-post instant messages in this application, known as tweets (Safko, 2013).

e) Blogging

(Eley \& Tiley, 2009) is a Website regularly updated, displaying posts in reverse chronological order (newest at the top). These updates could take the form of newspaper reports, posts, or just the cool links people had come across. 


\section{Tourism}

The hospitality and tourism industries are the largest and fastest increasing industry groupings in the world. The UNWTO and the World Travel and Tourism Council (WTT C) Declare to have the following characteristics for the travel and tourism industry:

a) A 24-hour, 7-day, 52-week-a-year economic leader

b) Total contribution to the global gross domestic product (GDP) of $9 \%$

c) Employer of more than 272 million workers, or 1 in 11 of the total jobs in the world, and is predicted to be 1 in 10 by 2021

d) Leading provider of tax income

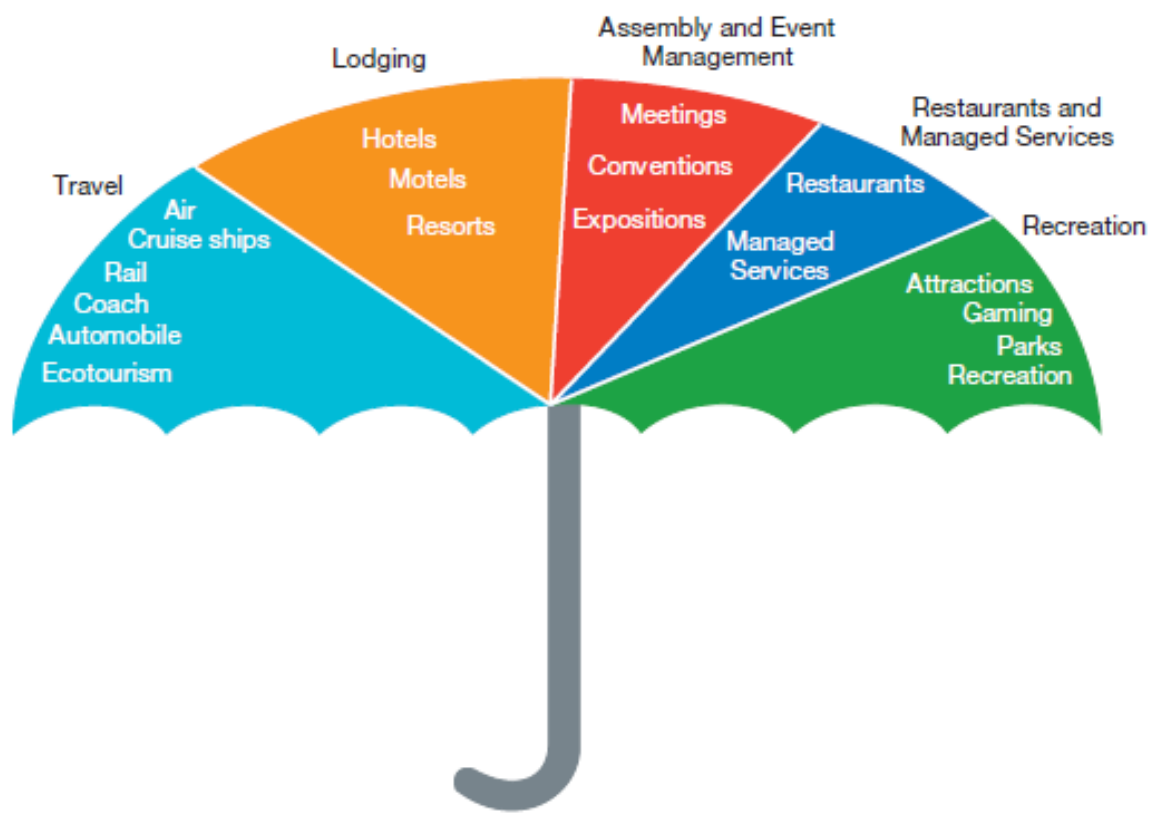

Figure 3: Scope of the Hospitality and Tourism Industries

Source : (Walker, 2017)

Consider all the reasons people are temporarily leaving their homes (whether alone or with others) for going to other locations near and far. Of several reasons, people are traveling. A travel away from home might be for holidays, jobs, attending a meeting, or maybe even visiting a college campus, just to name a few. Regardless of the reason, many sectors are required under the umbrella of travel and tourism to meet people's needs and wishes away from home.

McIntosh, Goeldner and Ritchie (1995) in (Fletcher, J., et al, 2018) four categories of motivation:

a) Physical motivators: Things connected to body and mind refreshment, fitness goals, sport and pleasure. It is shown that this community of motivators is connected to those activities which will reduce stress. The 
need to create a harmony or equilibrium is inherent in this type of approach.

b) Cultural motivators: Those characterized by the willingness of the tourists to see and learn more about other cultures, to learn more about the local country's people, their lifestyle, music, art, folklore, dance, etc.

c) Interpersonal motivators: This category involves a willingness to meet new people, to visit friends or family, to try new experiences and different looks. Travel is an escape from daily relationships or the home atmosphere with friends or family, or it is used for spiritual purposes.

d) Status and prestige motivators: Such involve a desire for continued education (i.e. personal growth, ego-enhancing, and sensual indulgence). These motivators are seen to be concerned with other people's need for attention and recognition, to raise the personal ego. This category also involves personal growth in hobby and education activities

Based on the motivation that exists in each tourists will determine the choice of tourist destinations they will be visited in their holiday seasons.

\section{Millennial Travelers}

Millennials generations are a highly attractive demographic because they have grown up in an world where technology offers a forum for personalization and instant gratification in all aspects of life. Millennials tend to spend their income faster and more often on the web, and particularly on social networks such as Facebook (Moreno et al, 2017).

According to kotler \& armstrong (2013) in (Moreno et al, 2017) Generation Millennials were born between 1977 and 2000. These are called baby boomers generations (born between 1946 and 1964), now nearly 83 million or more, eclipsing generation x members (born between 1965 and 1976) and becoming even bigger than baby boomer segment. Members of the millennium generation in the post-recession period are the Generation with greater financial constraints.

Millennials generation according to (BPS, 2018) is the generation born between 1980 and 2000, the next concept of generation Millennial Indonesia is the Indonesian population born between years 1980-2000.

The number of millennials reaches around 88 million or $33.75 \%$ of the total population of Indonesia. This proportion is higher than that of the previous generation such as Generation X $(25.74 \%)$ and the baby boom + veterans generation $(11.27 \%)$. Furthermore, the total of new generation $\mathrm{Z}$ reached around $29.23 \%$. There are about $55 \%$ of millennial generation who live in urban areas. (BPS, 2018:22). 


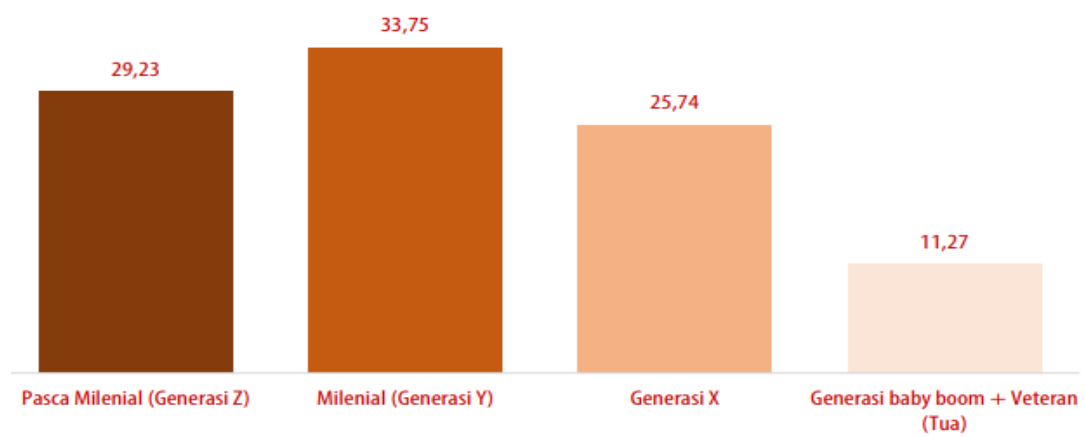

Figure 4: Population Composition by Generation (\%), 2017

Source : National Socio-Economic Survey (SUSENAS), BPS : 2018

According to Honeyball, 2017, millennial characteristics (general and travel): 1) An overwhelming number of millennials (80\%) will like to spend their money on an experience rather than on materialistic possession, indicating that travel may be a priority when spending disposable income.2) Social media, technology, internet and so on are similarly 'extremely important' or 'moderately important' when traveling.

\section{Research Methodology}

This research want to examine the significance importance Of Social Media Advertisement (e.g facebook, youtube, instagram, twitter and blogging) To gather information about a tourist destination among the Millennial groups. Research will be conducted in January - April 2020 to 72 student of Vocational Programme University Indonesia especially the student of second semester in tourism studies. The survey investigated the demographic characteristics of respondents, their active use of social media tools, and the perceived benefits of those tools. The first step is data collection by use of a self-administered questionnaire for quantitative investigation. Quantitative methods resulting in numerical or statistical summaries and, conversely, detailed survey data may be used to collect individual case histories and to present them in a narrative style. After completion of the data of questionnaires, the Social Sciences Software Statistical Program (SPSS) version 25 is used to analyze the data.

\section{Result}

The results of this research, it is known that the number of respondents was 72 people consisting of 24 men or $33.3 \%$ and 48 women or $66.7 \%$. Based on the age factor, it was found that $100 \%$ of respondents had an age between 17-23 years old, in accordance with the author's goal that this study was specifically for young travelers. Based on their reasons to fill vacation time by traveling, as many as 67 respondents or $93.1 \%$ they want Refreshing (refresh their mind from their usual routine of studying and doing assignments during lectures) and as much as $51.4 \%$ of respondents enjoy traveling when do it with their families ( Parents, 
brothers, sisters, etc.) and $38.9 \%$ enjoy traveling with classmates or organizations on campus. The results of the questionnaire is 67 respondents or about $93.1 \%$ they want to visit their holiday to enjoy in natural attractions such as (mountains and sea) then $4.2 \%$ spending their holidays to visit shopping center area.

The results of the questionnaire analysis, it is known that the respondents in this case are millennial generations, they are ascertained active every day on social media, 28 people or $38.9 \%$ of respondents play social media for 1-6 hours / day, 26 people or 36,1\% for 7-13 hours / day and 17 people or $23.6 \%$ play social media for 14-20 hours / day.

In this study there were only 5 (five) types of social media choices provided by researchers including: facebook, youtube, instagram, twitter and blog, as many as 41 people or $56.9 \%$ chosed Instagram as the most popular social media to find information when arranging their vacation. For more details, it can be seen in the diagram below about the types of social media that are interested in millennial generation children in finding information about tourist attractions to fill their holidays..

Table 1: Types of Social Media Respondents' Choice

\begin{tabular}{clcc}
\hline & & Frequency & Percent \\
\hline \multirow{2}{*}{ Valid } & Youtube & 24 & 33.3 \\
& Instagram & 41 & 56.9 \\
& Twitter & 5 & 6.9 \\
& Blog & 2 & 2.8 \\
& Total & 72 & 100.0 \\
\hline
\end{tabular}

Source : data from researchers

The results of a brief interview with respondents, there are various reasons they chose intagram as a social media to find information about tourist destinations including: 1) currently Instagram is one of the social media platforms that they use frequently, 2) at this time tourist destinations are starting to use Instagram as promotion media both domestically and abroad such as: visit bogor, visitsulsel.id, visitlampung, visitmelbourne, visit.dubai etc. 3) Instagram is famous with icon "\#" or hashtags, Instagram users only write \# followed by the desired information, it will get the information needed quickly. Example: \#wisatakulinerjogya \#wisataalambandung \#wisatabudayabaduy etc.

\section{E. Discussion}

The important factors in social media as a tool for the promotion of a tourist attraction that is in addition to complete and easily obtained information, also requires the aesthetic value of photographs and videos about tourist attractions, as many as $87.5 \%$ or as many as 63 people survey results to respondents they are interested in visiting a tourist destination because of the photos and videos showed on social media. 
The role of social media is not only important for potential tourists, but also very important for the destination manager and tourist attraction in promoting their products and services. When the tour manager has a good product and visitors are satisfied with the products and services they get, this social media is a free promotional tool for tourist managers. Currently, almost all tourists, especially millennials will share their experiences through stories, photos and videos during their vacation activities in a tourist site, so they will promote and provide recommendations on tourist attractions they have visited to potential tourists through their social media. Can be seen in the data below:

Table 2. Sharing The Experience In Social Media

\begin{tabular}{llrrrr}
\hline & & Frequency & Percent & Valid Percent & \multicolumn{2}{c}{ Pumulative } \\
Valid & Yes & 69 & 95,8 & 95,8 & 95,8 \\
\cline { 2 - 6 } & No & 3 & 4,2 & 4,2 & 100,0 \\
\cline { 2 - 6 } & Total & 72 & 100,0 & 100,0 & \\
\hline
\end{tabular}

Source : data from researchers

Based on the data above that of $96 \%$ of respondents will share their experiences during their action time, they will promote their holiday through their personal social media such as instagram stories, photos and videos.

From the results of data analysis obtained during this study, it can be seen that social media is very important at this time for millennials generation, especially when they will finding the information about tourism destinations to fill their holidays, This conditions needs to be considered for the tourism management when managing the tourism products, hopefully the visitors will happy, satisfied and get beautiful memories that can not be forgotten. in order to be able to tell experiences and make good comments on social media and become promotional tools for the management of tourist destinations.

\section{F. Conclusion}

1. Based on the results of this research currently social media platforms that are of interest to millennials in finding information when planning their vacation, includes : Instagram 56.9\%, YouTube 33.3\%, Twitter 6.9\% and Blogger 28\%.

2. According to respondents in this study social media play an important role today when they are looking for the information they need because the information is easy to find, the information presented is based on direct experience felt by the information writer, and almost 1-6 hours/day Millennials fill their time by playing social media.

3. The tourism attraction managements need to active and always updating to publish factual information, photos and videos on their official social media account, related to all activities, facilities, amenities etc. It should be noted, when they publish their photo video and information must be accordance with the original conditions in the tourist attraction in order to maintain trust and achieve visitor satisfactions. 
4. For The Future research can examine the techniques of managing social media in other to effective and efficient when promoting the tourism object to get more visitor.

\section{REFERENCES}

Eley, B. \& Tilley, S. (2009). Online Marketing Inside Out. Australia: SitePoint Pty Ltd.

Fletcher, J. M., Lyon, G. R., Fuchs, L. S., \& Barnes, M. A. (2018). Learning disabilities: From identification to intervention. Guilford Publications.

Gibbs, M., Meese, J., Arnold, M., Nansen, B., \& Carter, M. (2015). \# Funeral and Instagram: Death, social media, and platform vernacular. Information, Communication \& Society, 18(3), 255-268.

Honeyball, E. (2017). Determining The Motivations Of Millennial Travellers In The Context Of Cultural Experiences In Southeast Asia (Doctoral dissertation, Cardiff Metropolitan University).

Kavoura, A., \& Stavrianeas, A. (2015). The importance of social media on holiday visitors' choices-the case of Athens, Greece. EuroMed Journal of Business, 10(3), 360.

Moreno, F. M., Lafuente, J. G., Carreón, F. Á., \& Moreno, S. M. (2017). The characterization of the millennials and their buying behavior. International Journal of Marketing Studies, 9(5), 135-144.

Sahin, G. G., \& Sengün, G. (2015). The effects of social media on tourism marketing: a study among university students. Management and Administrative Sciences Review, 4(5), 772-786.

Safko, L. (2013). How Much Did That New Customer Cost You?.

UNWTO. (2019, 29 August). Tourism Enjoys Continued Growth Generating Usd 5 Billion Per Day, access from https://www.unwto.org/global/pressrelease/2019-08-29/tourism-enjoys-continued-growth-generating-usd-5billion-day 